
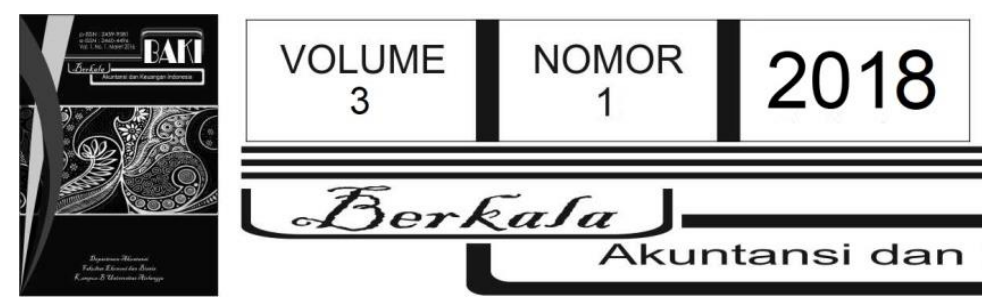

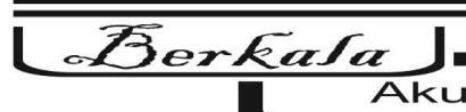

Akuntansi dan Keuangan Indonesia

\title{
Pengungkapan Perusahaan di Indonesia: Praktik Governance dan Struktur Kepemilikan
}

\author{
Rifky Nur Fadlillah ${ }^{1,2}$ \\ Iman Harymawan ${ }^{1}$ \\ ${ }^{1}$ Universitas Airlangga \\ ${ }^{2}$ rifqynur.fadlillah@gmail.com
}

INFO ARTIKEL

Histori Artikel:

Tanggal Masuk 15 Januari 2018

Tanggal Diterima 27 Maret 2018

Tersedia Online 24 Mei 2018

\section{Kata Kunci:}

corporate governance;

disclosure; struktur

kepemilikan

\begin{abstract}
A B S TRAK
Penelitian ini untuk mengetahui pengaruh pengungkapan (Disclosure) perusahaan setelah adanya peraturan menteri ESDM Nomor 7 Tahun 2012 dan Peraturan Menteri Keuangan Nomor 75/PMK.011/2012 di perusahaan tambang Indonesia. Data yang digunakan dalam penelitian ini berasal dari perusahaan pertambangan yang terdaftar di BEI tahun 2010-2014 dengan total perusahaan pertambangan 184. Teknik analisis yang digunakan adalah dengan metode analisis regresi linier berganda dengan bantuan software STATA 14.0. Praktik Corporate Governance dan struktur kepemilikan merupakan variable yang akan diuji apakah akan berpengaruh pada pengungkapan dengan varibel kontrol size, ROA, dan leverage. Hasil dari regresi menunjukkan bahwa pasca adanya peraturan pemerintah tentang perusahaan tambang dapat diketahui variabel praktik corporate governance dan variabel struktur kepemilikan tidak memiliki pengaruh terhadap banyak sedikitnya pengungkapan yang dilakukan oleh perusahaan tambang.
\end{abstract}

\section{Pendahuluan}

Pengungkapan atas laporan keuangan menjadi hal yang penting untuk menjadi ukuran dari pemegang saham atas kepercayaan kepada perusahaan tersebut. Gunawan et al. (2009) meneliti pengungkapan perusahaan dalam laporan tahunan perusahaan yang terdaftar di bursa efek Indonesia selama periode 2003-2006 dan menemukan bahwa perusahaan di industri lingkungan sensitif, seperti pertambangan, cenderung mengungkapkan informasi lingkungan yang lebih banyak dibandingkan dengan perusahaan yang lain industri.

Jika dikaitkan dengan teori Agency Theory dalam teori keagenan dinyatakan bahwa sulit untuk mempercayai bahwa manajemen (agent) akan selalu bertindak berdasarkan kepentingan 
prinsipal, sehingga diperlukan monitoring dari shareholders. Agency problems timbul karena orang cenderung untuk mementingkan dirinya sendiri dan munculnya konflik ketika beberapa kepentingan bertemu. Dengan adanya agency problem maka dapat menimbulkan agency cost. Ashbaugh, Collins, dan Lafond (2009) menemukan bahwa biaya agency terjadi akibat adanya asimetri informasi hal ini dikarenakan pemegang saham tidak dapat mengamati perilaku manajer secara langsung selain itu, masalah moral hazard dan adverse selection dapat terjadi. Untuk mengurangi asimetris informasi antara manajemen dan pemegang saham, perusahaan harus meningkatkan keterbukaan (Lang dan Lundholm 1993)

Hal ini, dapat dikaitkan dengan peraturan Menteri ESDM Nomor 7 Tahun 2012 dan Peraturan Menteri Keuangan Nomor 75/PMK.011/2012 tentang peningkatan nilai tambah mineral dan penetapan barang ekspor yang dikenakan tarif bea keluar. Dengan adanya ketentuan peraturan yang telah dibuat oleh Menteri ESDM maka, dapat mempengaruhi kegiatan operasianal maupun produksi dari perusahaan tambang yang ada di Indonesia. Penelitian lain menyatakan bahwa tingkat pengungkapan perusahaan dipengaruhi oleh posisi kompetitif mereka di industri. Studi ini menemukan bahwa perusahaan cenderung enggan mengungkapkan informasi jika perilaku ini membahayakan posisi kompetitif mereka di industri (Darrough dan Stoughton 1990; Dye 2001).

Studi sebelumnya umumnya berfokus meneliti pengaruh struktur kepemilikan terhadap nilai perusahaan atau kinerja perusahaan (Claessens, Djankov, Fan, dan Lang 2002; Morck, Shleifer, dan Vishny 1988; Thomsen, Pedersen, dan Kvist 2006) namun studi empiris yang menyelidiki pengaruh struktur kepemilikan pada pengungkapan Perusahaan di pasar negara berkembang relatif jarang khususnya di Indonesia. Selanjutnya, studi empiris baru yang menyelidiki pengaruh struktur kepemilikan terhadap pengungkapan perusahaan dengan mempertimbangkan kemungkinan hubungan non-linear antara struktur kepemilikan dengan pengungkapan perusahaan (Chau dan Gray 2010). Utama (2012) melakukan penelitian terhadap pengungkapan laporan perusahaan dengan mengunakan proksi faktor internal dan faktor eksternal perusahaan hasil menunjukkan bahwa praktek Corporate Governance, total aset, dan kompetisi memiliki pengaruh positif pada pengungkapan perusahaan.

Dengan demikian, dapat dijadikan bahan penelitian dengan memeberikan manfaat atau informasi bagi para investor untuk berinvestasi kepada perusahaan pertambangan setelah terjadinya peraturan menteri di Indonesia. Sisa dari artikel ini disusun sebagai berikut: Bagian 2 mengembangkan penelitian hipotesis; Bagian 3 menjelaskan sampel dan variabel; Bagian 4 menentukan model empiris, dan menyajikan hasil utama dan hasil regresi; Bagian 5 meringkas makalah dan menyajikan ucapan penutup..

\section{Tinjauan Pustaka}


Pengungkapan (Disclosure) didefinisikan sebagai penyediaan sejumlah informasi yang dibutuhkan untuk pengoperasian secara optimal pasar modal yang efisien (Suhardjanto dan Wardhani 2010). Laporan tahunan merupakan media bagi perusahaan untuk menyampaikan informasi perusahaan baik yang berupa kondisi keuangan maupun informasi laiinya kepada pemegang saham, kreditur, dan stakeholder lainnya (Narsa dan Isnalita 2017). Menurut Suhardjanto and Wardhani (2010) informasi yang diungkapkan dalam laporan tahunan dapat dikelompokkan menjadi dua, yaitu pengungkapan wajib yang didasarkan pada ketentuan (mandatory disclosure) dan pengungkapan yang bersifat sukarela (voluntary disclosure).

Agency theory berkaitan dengan penyelesaian dua masalah, yaitu pertama, agency problem muncul ketika tujuan principal dan konflik agen sulit atau mahal bagi principal untuk memverifikasi apa yang sebenarnya agen lakukan. Hal ini terjadi karena principal dan agen memiliki preferensi risiko yang berbeda sehingga memilih tindakan yang berbeda (Eisenhardt 1989). Manajer dapat bertindak bertentangan dengan kepentingan dari pemberi pinjaman. Pemberi pinjaman akan mengantisipasi perilaku ini dengan menaikkan suku bunga atas pinjaman tersebut. akibatnya, manajer memiliki insentif untuk bertindak tidak bertentangan kepentingan dengan pemberi pinjaman. Dengan cara memasukkan persyaratan dalam perjanjian dimana manajer setuju membatasi pinjaman tambahan saat outstanding (Scott 2012)

Untuk mengurangi asimetris informasi antara manajemen dan pemegang saham, perusahaan harus meningkatkan keterbukaan. Pengungkapan dapat disediakan melalui pengungkapan wajib dan pengungkapan sukarela (baik keuangan dan non-keuangan informasi). Perusahaan harus mengambil inisiatif untuk mengungkapkan hal-hal selain disyaratkan dalam peraturan perundang-undangan, akan tetapi hal yang dapat membantu proses pengambilan keputusan oleh stakeholders (Juniarti dan Sentosa 2010).

Dalam meningkatkan pengungkapan guna mwngurangi agency problem diperlukan tata kelola perusahaan (Corporate governance) yang baik dalam hal ini akan dapat terjadi sistem pengawasan dan pemonitoring. Corporate governance adalah proses dan struktur yang diterapkan dalam menjalankan perusahaan dengan tujuan utama untuk meningkatkan nilai pemegang saham dalam jangka panjang dengan tetap memperhatikan kepentingan stakeholders lainnya.

Diclosure juga erat kaitannya dengan struktur kepemilikan guna mengurangi agency problem. Struktur kepemilikan terbagi menjadi kepemilikan manajerial, kepemilikan blockholder dan kepemilikan pemerintah.Berdasarkan penelitian tersebut bahwa kepemilikan manajerial rendah dan kepemilikan pemerintah yang signifikan dapat meningkatkan pengungkapan sukarela. Dalam penelitian ini mengambil kepemilikan blockholder dikarenakan kepemilikan blockholder merupakan sebagai shareholder yang kepemilikannya paling sedikit $5 \%$ atas saham perusahaa. Juniarti and Sentosa (2010) mengemumakan bahwa, pemegang saham potensial diharapkan mempunyai kekuasan yang lebih besar dalam memonitoring manejemen, 
kerena kinerja mereka terkait erat dengan kinerja keuangan perusahaan.Pendapat ini didukung oleh Anderson, Mansi, dan Reeb (2003); Chau dan Gray 2010; Lenssen et al., 2011). Oleh karena itu diharapkan bahwa pengungkapan sukarela meningkat, dengan meningkatnya kepemilikan Blockholder.

Dalam penetepan pengungkapan terdapat variabel control yaitu variabel ukuran perusahaan (size). size perusahaan adalah suatu skala dimana dapat diklasifikasikan besar kecilnya perusahaan, dapat dinyatakan dalam total aktiva yang dimiliki oleh perusahaan meliputi aktiva tetap, aktiva tidak berwujud dan aktiva lain-lain. Sehingga hal ini dapat memberikan pengaruh besar kecilnya pengungkapan yang diharuskan oleh suatu perusahaan. Selain size pada penelitian ini juga menyertakan Variabel ROA dan Leverage dikarenakan pada variabel tersebut memiliki pengaruh pada profitabilitas perusahaan kepada pemegang saham sehingga memiliki hubungan terhadap pengungkapan perusahaan.

Efektifitas Corporate Governance ditentukan oleh bagaimana mekanisme Corporate Governance tersebut bekerja dalam perusahaan (Utami, Suhardjanto, dan Hartoko 2012) Sebaik apapun suatu struktur Corporate Governance tetapi jika mekanisme atau prosesnya tidak berjalan sebagaimana mestinya maka tujuan akhir melindungi kepentingan pemegang saham dan stakeholders tidak akan pernah tercapai (Eng dan Mak 2003). Dalam hal ini, perusahaan juga harus memahami adanya agency theory atas kepentingan agen dengan principal sehingga dibutuhkan praktik Corporate Governance untuk mengawasi dan memantau kegiatan agen sebagai manajemen perusahaan kepada principal. Selanjutnya, Eng and Mak (2003) menemukan bahwa praktek CG yang lebih baik ditunjukkan oleh kepemilikan manajerial lebih rendah dan kepemilikan pemerintah yang signifikan meningkatkan perusahaan secara pengungkapan sukarela.

Corporate governance sendiri juga dapat memberikan manfaat pengendalian bagi dewan direksi, dewan komisaris, komite audit, struktur kepemilikan, dan pengungkapan finansial. Oleh Karena itu dan hal praktik corporate governance dalam penelitian menggunakan penilaian aspek-aspek seperti dewan komisaris, dewan direktur, komite audit, dan komisaris independen (Harford et al., 2012). Oleh Karena itu, penulis berasumsi bahwa:

Komite Audit merupakan salah satu komite yang dibentuk oleh Dewan Komisaris sebagai salah satu organ tambahan yang diperlukan dalam pelaksanaan prinsip GCG. Komite audit timbul sebagai akibat peran pengawasan dan dewan komisaris perusahaan pada umumnya belum memadai. Pentingnya Komite Audit dalam suatu perusahaan terbuka dikuatkan dengan Surat Edaran Ketua Bapepam No. Se-03/PM/2000 tentang Komite Audit. Ketentuan ini mewajibkan setiap perusahaan publik atau emiten untuk memiliki Komite Audit (Utama 2012).

\section{H1a: Audit Comite memiliki pengaruh positif terhadap Disclosure}


Dalam two-tier system, peran dewan komisaris dan dewan direksi dipisah secara jelas. Dewan komisaris akan mengawasi pelaksanaan pekerjaan yang dilakukan oleh dewan direksi. Dalam two tier system sangat jelas ada perbedaan antara fungsi pengambilan dan pelaksanaa kebijakan dengan fungsi pengawasan. Fungsi pengambilan kebijakan dan pelaksanaannya dijalankan oleh dewan direksi. Sedangkan fungsi pengawasan terhadap kebijakan yang dijalankan oleh dewan direksi dilakukan oleh dewan komisaris. Dalam menjalankan tugasnya yang begitu luas, Dewan Komisaris dapat membentuk berbagai komite yang membantu fungsi Dewan Komisaris agar berjalan secara lebih efektif. Utama (2012) ada dua tipe komite-komite dewan. Tipe yang pertama merupakan komite yang menjalankan peranan penting dalam memberikan masukan kepada manajemen dan dewan komisaris pada pengambilan keputusan bisnis yang penting bagi perusahaan, contohnya yaitu komite perencanaan strategis. Tipe yang kedua berhubungan dengan fungsi monitoring atau pengawasan dari dewan, seperti komite audit, komite remunerasi, dan komite nominasi. Komite-komite tersebut secara spesifik dapat meningkatkan akuntabilitas dari dewan sebagaimana mereka menyediakan pengawasan independen dari berbagai aktivitas dewan.

\section{H1b: Ukuran Dewan memiliki pengaruh positif terhadap Disclosure}

Kehadiran direksi independen pada dewan perusahaan adalah penting untuk memastikan kepada pemegang saham untuk pengungkapan lingkungan, karena itu memungkinkan perusahaan untuk mengejar kepentingan kedua pemegang saham dan pemangku kepentingan (Suhardjanto dan Wardhani 2010). Pengertian Agency Theory adalan desain kontrak yang dibuat untuk memotivasi agen agar sesuai dengan kepentingan principal ketika kepentingan agen bertentangan dengan principal (Scott 2012). Sehingga perusahaan diperlukan menerapkan agency theory untuk mengawasi agency problem dalam perusahaan untuk menyelaraskan antara tujuan agen dengan tujuan principal. Temuan sebelumnya tentang hubungan antara proporsi independen direksi dan tingkat pengungkapan keberlanjutan telah bervariasi. Beberapa studi menemukan hubungan positif antara kedua variabel misalnya, (Juniarti dan Sentosa 2010; Lang dan Lundholm 1993), sementara beberapa yang lain tidak menemukan hubungan antara dua variabel misalnya, (Cooke 1989).

Pemegang saham pengendali akan enggan untuk melakukan perilaku yang membahayakan mereka atas kekayaan pribadi. Selanjutnya, kebutuhan untuk pengungkapan sukarela akan lebih rendah karena ada keselarasan kepentingan antara pemegang saham pengendali dan non-pemegang saham pengendali yang menurunkan pengawasan lebih dalam. Tapi, pada tingkat yang lebih tinggi dari terkonsentrasi kepemilikan (lebih dari 25\%), pemegang saham pengendali cenderung mengejar keuntungan pribadi dan menyebabkan kerugian mereka ke pemegang saham minoritas (Efek kubu). Untuk mengatasi kubu potensi ini, lebih tinggi tingkat pengungkapan diperlukan karena tingkat kepemilikan terkonsentrasi meningkatkan. Kepemilikan blockholder merupakan sebagai shareholder yang kepemilikannya 
paling sedikit 5\% atas saham perusahaa.Jansen and Mackling (1976) mengemumakan bahwa, pemegang saham potensial diharapkan mempunyai kekuasan yang lebih besar dalam memonitoring manejemen, kerena kinerja mereka terkait erat dengan kinerja keuangan perusahaan.Pendapat ini didukung oleh Aboagye-Otchere et al. (2012); Eng dan Mak (2003). Oleh karena itu diharapkan bahwa pengungkapan sukarela meningkat, dengan meningkatnya kepemilikan Blockholder. Maka, penulis beranggapan bahwa:

\section{H2: Struktur Kepemilikan memiliki pengaruh positif terhadap Disclosure}

\section{Metodologi Penelitian}

Populasi dan sampel pada penelitian merupakan perusahaan pertambangan yang terdaftar pada BEI pada periode 2010-2015. Mencakup semua data keuangan dan annual report perusahaan pertambangan. Keseluruhan sampel pada penelitian sebanyak 184 perusahaan pertambangan.

\subsection{Pengukuran Variabel}

i. Variabel Pengungkapan

Kegiatan pengolahan data dilakukan dalam dua tahap. Tahap pertama yaitu berupa pemberian skor atas pengungkapan item-item yang ada pada laporan tahunan seperti yang dilakukan oleh Botosan (1997). Sedangkan tahap kedua adalah pengujian hipotesis.

ii. Variabel Praktik Tata Kelola Perusahaan (Corporate Governance Practice)

Dalam menentukan Praktik Corporate Governance terdapat dua analisis cara dalam memasukkan rumus, sebagai berikut:

a. BOARDSIZE $=B D+B C$

BOARDSIZE adalah analisis Praktik Corporate Governance yang merupakan penjumlahan dari jumlah Board Of Director (BD) dan jumlah Board Of Commisioners (BC) pada suatu perusahaan

b. AUDITCOMSIZE = $\sum$ AUDITCOMMITTEE

AUDITCOMSIZE adalah analisis Praktik Corporate Governance yang merupakan penjumlahan dari Audit Committee perusahaan.

iii. Variabel Struktur Kepemilikan (Ownership Structure)

Variabel independent berikutnya yaitu struktur kepemilikan (Ownership Structure) yang diproksikan dengan persentase besar pemegang saham kepemilikan (blockholder). Menurut Eng dan Mak (2003); Thomsen et al., (2006), kepemilikan blockholder adalah proporsi saham biasa yang dimiliki oleh pemegang saham utama 
(yaitu, kepemilikan saham $5 \%$ atau lebih). Persentase yang lebih tinggi dari pemegang saham besar menunjukkan kepemilikan lebih terkonsentrasi.

Adapun terdapat pula beberapa variabel kontrol yang digunakan pada penelitian ini, di antaranya adalah:

iv. Size

Size perusahaan diukur dengan total aktiva yang dimiliki perusahaan, kemudian akan ditransformasikan dalam logaritma natural untuk menyamakan nilai dengan variabel lain dikarenakan total aktiva perusahaan nilainya relative besar dibandingkan variabel-variabel lain dalam penelitian ini.

Adapun pengukurannya dengan menggunakan rumus:

$S I Z E=$ Total Aset Perusahaan

$S I Z E=\log$ Total Aset Perusahaan

v. Return On Assets (ROA)

Return on assets (ROA) digunakan untuk mengukur efektivitas perusahaan di dalam menghasilkan keuntungan dengan memanfaatkan aktiva yang dimilikinya. ROA diperoleh dengan cara membandingan antara net income after tax (NIAT) terhadap average total asset (Prawiranegara, 2012).

$\mathrm{ROA}=$ Laba setelah pajak / Total Aset

\section{vi. Leverage}

Leverage dapat diartikan sebagai tingkat ketergantungan perusahaan terhadap hutang dalam membiayai kegiatan operasinya, dengan demikian leverage juga mencerminkan tingkat resiko keuangan perusahaan (Sembiring 2005). Dalam penelitian ini, indikator yang digunakan untuk mengukur tingkat leverage adalah Debt To Equity Ratio (DER). Adapun pengukuruan dalam penelitian ini dengan menggunakan rumus:

DER $=$ Total Hutang / Total Ekuitas

\section{Analisis dan Pembahasan}

\subsection{Statistik Deskriptif}

Statistik deskriptif memberi informasi tentang gambaran umum tentang variable-variabel yang aka diuji. Mengenai deskripsi dari variabel yang digunakan dalam penelitian, yaitu disclousure, praktik corporate governance (akan diproksikan board size dan audit commissioner), struktur kepemilikan, aset, Leverage, serta ROA perusahaan. Statistik deskriptif memberikan informasi mengenai nilai minimum, nilai maksimum, nilai rata-rata (mean), dan nilai standar deviasi dari masing- masing variabel penelitian. Pada Statistik deskriptif dalam penelitian ini dapat dilihat pada tabel berikut: 
Tabel 4.1. Analisis Deskriptif

\begin{tabular}{lrrrrrr} 
& $\mathrm{N}$ & Minimum & Maximum & Mean & \multicolumn{1}{c|}{ Std. Deviation } \\
DSCORE & 184 &, 4857143 &, 8285714 &, 625 &, 080926 \\
BLOCKHOLDER & 184 &,- 8745906 & 3,476099 & 1,032921 & 1,042257 \\
S & & 2 & 5 & 3,070652 &, 5436244 \\
AUDITCOMSIZE & 184 & 4 & 15 & 9,11413 & 2,71869 \\
BOARDSIZE & 184 & 3062 & 85937953 & 10200000 & 16600000 \\
SIZE & 184 & $-27,23$ & 57,7 & 5,009665 & 11,95431 \\
ROA & 184 & 20 & 0,6285742 & 5,887033 \\
LEVERAGE & 184 & $-39,99031$ & 20
\end{tabular}

Sumber: data diolah dengan STATA. Tabel menunjukkan statistik deskriptif dari semua variabel yang digunakan dalam penelitian ini. Sampel dari 184 perusahaan tercatat di Bursa Efek Indonesia (BEI) untuk periode 2010-2014.

Dari tabel 4.1 di atas dapat diketahui jumlah pengamatan yang diteliti sebanyak 184 pengamatan, berdasarkan 5 periode terakhir laporan keuangan tahunan (2012-2014), dalam statistik deskriptif dapat dilihat nilai minimum, maksimu, mean, serta tingkat penyebaran (standar deviasi) dari masing-masing variabel yang diteliti.

Pada tabel 4.1 diatas merupakan hasil dari statistik deskriptif variabel-variabel penelitian dari tahun pengamatan 2010 sampai 2014 yang masing-masing variabel berjumlah 184. Mean dari variabel DSCORE adalah 0.625, BLOCKHOLDERS adalah 1.032921, sedangkan AUDITCOMSIZE dan BOARDSIZE adalah 3.070652 dan 9.11413. untuk variabel kontrol rata-rata Size (10.200.000), ROA (5.009665), dan LEVERAGE (0.6285742).

\subsection{Analisi Regresi}

Penelitian ini melakukan analisis empiris untuk menilai pengaruh antara pengungkapan terhadap Pratik corporate governance dan struktur kepemilikan pada perusahaan pertambangan yang terdaftar pada bursa efek Indonesia pada tahun 2010 sampai 2014. Penelitian ini menggunakan model regresi Ordinary Least Square (OLS) dengan menggunakan STATA/MP 14.0 untuk melakukan analisis regresi.

4.2.1 Pengaruh pengungkapan terhadap Pratik corporate governance dan struktur kepemilikan Perusahaan

Penelitian ini melakukan analisis empiris untuk menguji pengaruh antara hubungan pengungkapan dengan Praktik corporate governance dan Stuktur kepemilikan serta dengan variable kontrol size, ROA, leverage pada perusahaan pertambangan tahun 2010-2015.

Adapun rumus yang dipakai untuk model regresi adalh sebagai berikut: 
DSCORE $=a+b_{1} \cdot$ BLOCKHOLDERS $+b_{2} \cdot$ BOARDSIZE $+b_{3} \cdot$ INDEPENDENTBOARD + $b_{4} \cdot A U D I T C O M S I Z E+b_{5} \cdot$ SIZE $+b_{6} \cdot R O A+b_{7} \cdot$ LEV $+e$

Tabel 4.2. Analisis Regresi

\begin{tabular}{|c|c|c|c|}
\hline \multirow{2}{*}{ Variabel } & \multicolumn{2}{|c|}{ Predicted } & \\
\hline & Sign & & \\
\hline BLOCKHOLDERS & - & $\begin{array}{l}-0.002 \\
(-0.30)\end{array}$ & $\begin{array}{l}-0.002 \\
(-0.36)\end{array}$ \\
\hline AUDITCOMSIZE & + & $\begin{array}{l}0.021^{*} \\
(1.88)\end{array}$ & $\begin{array}{l}0.021^{\text {*** }} \\
(2.66)\end{array}$ \\
\hline BOARDSIZE & + & $\begin{array}{l}0.006^{\star * *} \\
(2.68)\end{array}$ & $\begin{array}{l}0.006^{\star * *} \\
(3.17)\end{array}$ \\
\hline LNSIZE & + & $\begin{array}{l}0.004 \\
(1.12)\end{array}$ & $\begin{array}{l}0.004 \\
(1.08)\end{array}$ \\
\hline ROA & $?$ & $\begin{array}{l}-0.000 \\
(-0.81)\end{array}$ & $\begin{array}{l}-0.000 \\
(-0.89)\end{array}$ \\
\hline LEV & $?$ & $\begin{array}{l}0.000 \\
(0.04)\end{array}$ & $\begin{array}{l}0.000 \\
(0.07)\end{array}$ \\
\hline _cons & & $\begin{array}{l}0.445^{\text {** }} \\
(7.60)\end{array}$ & $\begin{array}{l}0.4425^{\star *} \\
(7.31)\end{array}$ \\
\hline Year dummies & & Included & Included \\
\hline r2 & & 0.096 & 0.096 \\
\hline r2_a & & 0.044 & 0.044 \\
\hline$N^{-}$ & & 184 & 184 \\
\hline
\end{tabular}

Sumber: proses data STATA, signifikansi level ${ }^{*} 10 \%,{ }^{*} 5 \%,{ }^{* \star *} 1 \%$

Pada hasil Tabel 4.3 menunjukkan bahwa koefisien tabel 1 variabel AUDITCOMSIZE adalah 0,021 dengan tingkat signifikan 10\%,dengan nilai $\mathrm{t}$ adalah 1,87 dan BOARDSIZE memiliki koefisien adalah 0,006 dengan tingkat signifikan $1 \%$, dengan nilai t 2,63. Sedangkan pada tabel 2 koefisien variabel AUDITCOMSIZE adalah 0,021 dengan tingkat signifikan $5 \%$,dengan nilai t adalah 2,64 dan BOARDSIZE memiliki koefisien adalah 0,006 dengan tingkat signifikan $1 \%$, dengan nilai t 3,08. AUDITCOMSIZE dan BOARDSIZE merupakan proksi dari praktik Corporate Governance dimana pada tabel 4.3 menunjukkan bahwa pratik Corporate Governance memiliki pengaruh positif atau signifikan terhadap pengungkapan (disclousure) pada suatu perusahaan. Hal ini, sesuai dengan pernyataan Hartoko et al. (2012) dimana pada suatu perusahaan untuk meningkatkan suatu pengungkapan perusahaan yang baik diperlukan tata kelola perusahaan yang baik serta melakukan pengawasan dan pengendalian terhadap dewan direksi, dewan komisaris, komite audit, struktur kepemilikan, dan pengungkapan finansial.

Tabel 4.2 variabel BLOCKHOLDERS adalah $-0,002$, dengan nilai $t$ adalah $-0,30$ dan tabel 2 variabel BLOCKHOLDERS adalah -0,002,dengan nilai $t$ adalah $-0,37$. Hal ini membuktikan bahwa BLOCKHOLDERS sebagai proksi struktur kepemilikan tidak signifikan terhadap disclousure atau pengaruh negative. Hal ini sesuai dengan hasil Chau dan Gray (2010) yang menemukan hubungan non linier antara pengungkapan perusahaan dan kepemilikan blockholder. Jadi dalam hal ini struktur kepemilikan tidak memiliki pengaruh 
terhadap banyak sedikitnya pengungkapan yang dilakukan perusahaan.

$\begin{aligned} \text { DSCORE } & =a+b_{1} \cdot \text { BLOCKHOLDERS X PASCA }+b_{2} \cdot \text { BOARDSIZE X PASCA + } \\ & b_{3} \cdot \text { AUDITCOMSIZE } X \text { PASCA }+b_{4} \cdot \text { BLOCKHOLDERS }+ \\ & b_{5} \cdot \text { BOARDSIZE }+b_{6} \cdot \text { AUDITCOMSIZE }+b_{7} \cdot \text { SIZE }+b_{8} \cdot \text { ROA }+b_{6} \cdot \text { LEV }+e\end{aligned}$

Tabel 4.3. Analisis Regresi Pasca dan Sebelum Ada Peraturan

\begin{tabular}{|c|c|c|c|c|}
\hline Variabel & Predicted & \multicolumn{3}{|c|}{ DSCORE } \\
\hline & Sign & 1 & 2 & 3 \\
\hline BLOCK X PASCA & & $\begin{array}{l}-0.001 \\
(-0.09)\end{array}$ & & \\
\hline AUDITCOM X PASCA & & & $\begin{array}{l}-0.151 \\
(-0.67)\end{array}$ & \\
\hline BOARDSIZE X PASCA & & & & $\begin{array}{l}0.001 \\
(0.11)\end{array}$ \\
\hline PASCA & & $\begin{array}{l}0.004 \\
(0.18)\end{array}$ & $\begin{array}{l}0.049 \\
(0.68)\end{array}$ & $\begin{array}{l}-0.002 \\
(-0.04)\end{array}$ \\
\hline BLOCKHOLDERS & - & $\begin{array}{l}-0.001 \\
(-0.10)\end{array}$ & $\begin{array}{l}-0.002 \\
(-0.31)\end{array}$ & $\begin{array}{l}-0.002 \\
(-0.30)\end{array}$ \\
\hline AUDITCOMSIZE & + & $\begin{array}{l}0.021^{*} \\
(1.86)\end{array}$ & $\begin{array}{l}0.030^{*} \\
(1.68)\end{array}$ & $\begin{array}{l}0.021^{*} \\
(1.88)\end{array}$ \\
\hline BOARDSIZE & + & $\begin{array}{l}0.006^{\star \star \star} \\
(2.68)\end{array}$ & $\begin{array}{l}0.006^{* * *} \\
(2.60)\end{array}$ & $\begin{array}{l}0.006 \\
(1.51)\end{array}$ \\
\hline LNSIZE & + & $\begin{array}{l}0.004 \\
(1.12)\end{array}$ & $\begin{array}{l}0.004 \\
(1.17)\end{array}$ & $\begin{array}{l}0.004 \\
(1.12)\end{array}$ \\
\hline ROA & $?$ & $\begin{array}{l}-0.000 \\
(-0.81)\end{array}$ & $\begin{array}{l}-0.000 \\
(-0.84)\end{array}$ & $\begin{array}{l}-0.000 \\
(-0.78)\end{array}$ \\
\hline LEV & $?$ & $\begin{array}{l}0.000 \\
(0.06)\end{array}$ & $\begin{array}{l}6.590 \\
(0.01)\end{array}$ & $\begin{array}{l}0.000 \\
(0.04)\end{array}$ \\
\hline cons & & $\begin{array}{l}0.444^{\star \star \star} \\
(7.43)\end{array}$ & $\begin{array}{l}0.413^{\star * *} \\
(5.51)\end{array}$ & $\begin{array}{l}0.447^{\star \star \star} \\
(7.13)\end{array}$ \\
\hline Year dummies & & Included & Included & Included \\
\hline r2_a & & 0.038 & 0.041 & 0.039 \\
\hline$N$ & & 184 & 184 & 184 \\
\hline
\end{tabular}

Sumber: proses data STATA, signifikansi level ${ }^{*} 10 \%,{ }^{* \star} 5 \%,{ }^{* *} 1 \%$

Pada hasil Tabel 4.4 menunjukkan hasil dari pasca penerapan peraturan Menteri ESDM Nomor 7 Tahun 2012 dan Peraturan Menteri Keuangan Nomor 75/PMK.011/2012 dimana variabel AUDITCOMSIZE pada tabel 2 dengan koefisien 0,030 dengan tingkat signifikan 10\%, dengan nilai $t$ adalah 1,68 sebelum adanya peraturan sedangan variabel AUDITCOMSIZE $X$ PASCA dengan koefiesien $-0,151$ dan nilai $t$ adalah $-0,67$ setelah adanya peraturan. BOARDSIZE pada tabel 3 dengan koefisien 0,006 dengan nilai t adalah 1,51 sebelum adanya peraturan sedangan variabel BOARDSIZE X PASCA dengan koefiesien 0,001 dan nilai t adalah 0,11 setelah adanya peraturan. Hal ini menjelaskan pada variabel AUDITCOMSIZE sebelum adanya peraturan berpengaruh positif terhadap pengungkapan yang berarti apabila komite audit pada suatu berusahaan itu banyak akan mempengaruhi banyaknya pengungkapan yang akan dilakukan oleh perusahaan. Sedangkan setelahnya adanya peraturan berpengaruh negatif 
yang menjadikan banyaknya komite audit tidak berpengaruh terhadap pengungkapan perusahaan.

BLOCKHOLDERS pada tabel 1 dengan koefisien $-0,001$ dengan nilai t adalah $-0,10$ sebelum adanya peraturan sedangan variabel BLOCKHOLDERS X PASCA dengan koefiesien 0,001 dan nilai t adalah $-0,09$ setelah adanya peraturan.

\subsection{Pembahasan}

Hipotesis pada penelitian ini menyatakan bahwa praktik corporate governance dalam penelitian ini diprosikan dengan komite audit dan ukuran dewan memiliki pengaruh untuk melakukan pengungkapan (disclosure) pada perusahaan. Dari hasil analisis yang dilakukan dalam penelitian ini analisis regresinya menunjukan bahwa untuk komite audit sebelumnya adanya peraturan Menteri menunjukkan adanya pengaruh terhadap pengungkapan yang berarti hipotesis diterima. Hal ini sesuai dengan penelitian yang dilakukan Harford et al. (2012) bahwa Komite Audit merupakan salah satu komite yang dibentuk oleh Dewan Komisaris sebagai salah satu organ tambahan yang diperlukan dalam pelaksanaan prinsip GCG.

Proksi praktik corporate governance adalah variabel ukuran dewan hipotesis penelitian ini menyatakan bahwa tidak ada pengaruh dalam melakukan pengungkapan perusahaan. Pada hasil regresi yang dilakukan baik sebelum dan pasca setelah adanya peraturan Menteri variabel ukuran dewan tidak berpengaruh dan memiliki pengaruh negatif terhadap kegiatan pengungkapan perusahaan yang artinya hipotesis ditolak. Hal ini tidak sesuai dengan Michelon dan Parbonetti (2012) menyatakan bahwa banyaknya jumlah dewan pada perusahaan akan meningkatkan pengungkapan perusahaan tersebut karena tingkat independensi pengawasan terhadap perusahaan akan lebih baik. Maka pada penelitian ini menyatakan bahwa jumlah dewan yang banyak tidak meningkatkan pengungkapan perusahaan karena jumlah dewan tersebut belum bisa memaksimalkan fungsi dari praktik akuntansi dan pengawasan terhadap manajer perusahaan dalam peningkatan pengungkapan yang kurang efektif.

Hipotesis kedua yaitu variabel struktur kepemilikan yang diproksikan blockholders pada hipotesis penelitian ini menyatakan bahwa tidak ada pengaruh dalam melakukan pengungkapan perusahaan. Pada hasil regresi yang dilakukan baik sebelum dan pasca setelah adanya peraturan Menteri variabel blockholders tidak berperngaruh dan memiliki pengaruh negatif terhadap kegiatan pengungkapan perusahaan yang artinya hipotesis ditolak. Hal ini sesuai dengan penelitian yang telah dilakukan oleh Chau dan Gray (2010) yang menemukan hubungan non linier antara pengungkapan perusahaan dan kepemilikan blockholder. Hal ini

dikarenakan, walaupun kepemilikan blockholders memiliki kontrol terhadap kegiatan 
perusahaan akan tetapi, keputusan untuk melakukan pengungkapan berada dalam wewenang manajemen perusahaan.

\section{Simpulan}

Berdasarkan hasil pengujian yang telah didapat serta pembahasan yang telah dijelaskan pada bab sebelumnya, maka dapat disimpulkan beberapa hal sebagai berikut:

1. Sebelum adanya penerapan peraturan menteri komite audit (audit committee) banyak sedikitnya dapat memberikan pengaruh terhadap banyak sedikitnya pengungkapan perusahaan dengan memberikan pengawasan terhadap manajer perusahaan, yang berarti Hipotesis 1a diterima. Sedangkan pasca penerapan peraturan menteri banyak sedikitnya komite audit tidak memiliki pengaruh terhadap pengungkapan suatu perusahaan.

2. Ukuran dewan merupakan jumlah dari dewan komisari dan dewan direktur. Pasca terjadinya penerapan peraturan Menteri ESDM Nomor 7 Tahun 2012 dan Peraturan Menteri Keuangan Nomor 75/PMK.011/2012 dan sebelumnya pengungkapan yang dilakukan perusahaan terhadap jumlah ukuran dewan tidak memiliki pengaruh yang signifikan, yang berarti Hipotesis $1 \mathrm{~b}$ ditolak.

3. Pasca terjadinya penerapan peraturan Menteri ESDM Nomor 7 Tahun 2012 dan Peraturan Menteri Keuangan Nomor 75/PMK.011/2012 dan sebelumnya pengungkapan yang dilakukan perusahaan terhadap banyak sedikitnya struktur kepemilikan tidak memiliki pengaruh yang signifikan, yang berarti Hipotesis 2 ditolak. Hal ini sesuai dengan temuan yang dilakukan Chau dan Gray (2010) yang menemukan hubungan non linier antara pengungkapan perusahaan dan kepemilikan blockholder.

\section{Daftar Pustaka}

Aboagye-Otchere, F., Bedi, I., dan Ossei Kwakye, T. 2012. Corporate governance and disclosure practices of Ghanaian listed companies. Journal of Accounting in Emerging Economies, 2(2): 140-161.

Anderson, R. C., Mansi, S. A., dan Reeb, D. M. 2003. Founding family ownership and the agency cost of debt. Journal of financial economics, 68(2): 263-285.

Ashbaugh-Skaife, H., Collins, D. W., dan Lafond, R. 2009. The effect of SOX internal control deficiencies on firm risk and cost of equity. Journal of Accounting research, 47(1): 1-43.

Botosan, C. A. 1997. Disclosure level and the cost of equity capital. Accounting review: 323349.

Chau, G., dan Gray, S. J. 2010. Family ownership, board independence and voluntary disclosure: Evidence from Hong Kong. Journal of International Accounting, Auditing and Taxation, 19(2): 93-109. 
Claessens, S., Djankov, S., Fan, J. P., dan Lang, L. H. 2002. Disentangling the incentive and entrenchment effects of large shareholdings. The journal of finance, 57(6): 2741-2771.

Cooke, T. E. 1989. Voluntary corporate disclosure by Swedish companies. Journal of International Financial Management dan Accounting, 1(2): 171-195.

Darrough, M. N., dan Stoughton, N. M. 1990. Financial disclosure policy in an entry game. Journal of accounting and economics, 12(1): 219-243.

Dye, R. A. 2001. An evaluation of "essays on disclosure" and the disclosure literature in accounting. Journal of accounting and economics, 32(1): 181-235.

Eisenhardt, K. M. 1989. Agency theory: An assessment and review. Academy of management review, 14(1): 57-74.

Eng, L. L., dan Mak, Y. T. 2003. Corporate governance and voluntary disclosure. Journal of accounting and public policy, 22(4): 325-345.

Gunawan, J., Djajadikerta, H., dan Smith, M. 2009. An examination of corporate social disclosures in the annual reports of Indonesian listed companies. Asia Pacific Centre for Environmental Accountability Journal, 15(1): 13-36.

Harford, J., Mansi, S. A., dan Maxwell, W. F. 2012. Corporate governance and firm cash holdings in the US Corporate Governance: 107-138): Springer.

Jensen, M. C., dan Meckling, W. H. 1976. Theory of the firm: Managerial behavior, agency costs and ownership structure. Journal of financial economics, 3(4): 305-360.

Lang, M., dan Lundholm, R. 1993. Cross-sectional determinants of analyst ratings of corporate disclosures. Journal of Accounting research, 246-271.

Latan, H. 2014. Aplikasi Analisis Data Statistik untuk Ilmu Sosial Sains dengan Stata.

Lenssen, G., Blagov, Y., Bevan, D., Peters, S., Miller, M., dan Kusyk, S. 2011. How relevant is corporate governance and corporate social responsibility in emerging markets? Corporate Governance: The international journal of business in society, 11(4): 429-445.

Michelon, G., dan Parbonetti, A. 2012. The effect of corporate governance on sustainability disclosure. Journal of Management dan Governance, 16(3): 477-509.

Morck, R., Shleifer, A., dan Vishny, R. W. 1988. Management ownership and market valuation: An empirical analysis. Journal of financial economics, 20: 293-315.

Narsa, Niluh Putu Dian Rosalina Handayani, dan Isnalita Isnalita. 2017. SAK ETAP SEBAGAI SOLUSI OVERLOAD STANDAR AKUNTANSI BAGI UMKM. EKUITAS (Jurnal Ekonomi dan Keuangan) 1 (1) (2017): 44-65.

Scott, W. R. 2012. Financial Accounting Theory 6th edition. Toronto: Pearson Education Canada.

Sembiring, E. R. 2005. Karakteristik Perusahaan dan Pengungkapan Tanggung Jawab Sosial pada Perusahaan yang Tercatat di Bursa Efek Jakarta. Simposium Nasional Akuntansi, 7,:15-16.

Suhardjanto, D., dan Wardhani, M. 2010. Praktik intellectual capital disclosure perusahaan yang terdaftar di bursa efek Indonesia. JAAl, 14(1): 71-85.

Thomsen, S., Pedersen, T., dan Kvist, H. K. 2006. Blockholder ownership: Effects on firm value in market and control based governance systems. Journal of Corporate finance, 12(2): 246-269.

Utama, C. A. 2012. Company disclosure in Indonesia: Corporate governance practice, ownership structure, competition and total assets. Asian journal of business and accounting, 5(1).

Utami, W. D., Suhardjanto, D., dan Hartoko, S. 2012. Investigasi Dalam Konvergensi IFRS di Indonesia: Tingkat Kepatuhan Pengungkapan Wajib dan Kaitannya dengan Mekanisme Corporate Governance. Paper Dipresentasikan di Simposium Nasional Akuntansi XV, Banjarmasin. 